Мамедов О.Ю. Стратегия динамики региональной экономики: от модернизации экономики к модернизации производства!

УДК 338.23

DOI: $10.21779 / 2500-1930-2017-32-3-76-81$

\title{
О.Ю. Мамедов
}

\section{Стратегия динамики региональной экономики: от модернизации экономики к модернизации производства ${ }^{1}$}

Южный федеральный университет; Россия, 344002, г. Ростов-на-Дону, ул. М. Горького, 88; oktaj-mamedov@yandex.ru

В статье раскрываются вопросы модернизации российских региональных экономических систем. Даётся характеристика препятствий, которые предстоит преодолеть на пути модернизации региональной экономики. Доказывается необходимость преодоления диктата государства в экономике, без которого невозможна модернизация как на общероссийском, так и на региональном уровне. Доля имущества государства составляет более половины в богатстве общества, а с учетом косвенного контроля - свыше трех четвертей; государство является самым неэффективным собственником.

Автор предлагает на неопределенный период отказаться от требования обязательной легализации неформального сектора, тем самым освободив его от бремени налоговых обязательств. Показан гипертрофированный для Северо-Кавказского региона характер общероссийских негативных моментов: суперэтатизм, бюрократизм, централизм, коррупция, монополизм. На основании этого делается вывод о содержании модернизации северокавказской экономики: переход к альтернативной экономической модели, которой присущи минимальное присутствие государства в экономике, приоритетность позиций гражданского общества, расширение сферы свободного предпринимательства, реальная борьба с монополизмом.

Ключевые слова: бюрократизм, иентрализм, монополизм, модернизация, эффективная финансовая система, либерализащия.

Экономические аналитики обычно выступают экспертами по проблемам теории и практики модернизации региональных экономических систем $[12,14,19]$. Такая экспертиза требует честной оценки реальности, в которой находится экономика российских регионов.

Что касается состояния экономики южно-российских регионов, то её реалии во многом справедливо отражены в «Резолюции Дагестанского гражданского форума» [21]. Из этого документа следует, что модернизацию российских региональных экономических систем нельзя откладывать ни на день. Но практика пока к этому не готова как впрочем, и отечественная экономическая наука.

Тезисная характеристика препятствий, которые предстоит преодолеть на пути модернизации региональной экономики, сводится к следующему [9]:

1. Мы не использовали для модернизации возможности, предоставленные сидением на «сырьевой игле». Сможем ли мы сделать это сегодня, пересаживаясь на «несырьевую иглу»?

\footnotetext{
${ }^{1}$ Статья подготовлена по материалам доклада, представленного на III Международной научнопрактической конференции «Модернизация экономических систем: опыт и перспективы», которая прошла 27-28 апреля 2017 года в Дагестанском государственном университете (г. Махачкала, РФ).
} 
Мамедов О.Ю. Стратегия динамики региональной экономики: от модернизации экономики к модернизации производства!

2. Мы не преодолели «чересполосицу» рыночных и нерыночных сфер, а без этого модернизация невозможна [15]. Сможем ли мы снять это препятствие на пути модернизации?

3. Мы до сих пор не научились ни защищать, ни любить предпринимателей, а без этого модернизация невозможна. В состоянии ли мы это сделать теперь?

4. У нас до сих пор не получается обуздать рост социально-неэффективных расходов, а без этого модернизация невозможна. Собираемся ли мы создавать антизатратный механизм хозяйствования?

5. Модернизация региональной экономики невозможна без предоставления регионам реальной экономической самостоятельности посредством реорганизации бюджетного процесса [10]. Собираемся ли мы это сделать?

6. Мы уже сто лет не даём экономике развиваться по её собственным законам. А без такой свободы модернизация экономики невозможна. Между тем, выбирая между экономикой и политикой, мы всегда предпочитаем политику, принося ей в жертву экономику.

7. Почти не исследован вопрос о соотношении общероссийской и региональной модернизации, актуализирующий главный аспект: два уровня модернизации должны происходить синхронно или асинхронно? И совпадает ли их содержание?

8. В современной российской экономике главным субъектом по-прежнему остаётся государство: доля его имущества составляет более половины в богатстве общества, а с учетом косвенного контроля - свыше трех четвертей! И если мы в чём и убедились за прошедшие сто лет, так это в том, что государство является самым неэффективным собственником. Но вряд ли стоит ждать от наших чиновников, представляющих государство, помощи в переходе к альтернативной организации экономики, из которой выводится государство, а следовательно, и чиновники. А без преодоления диктата государства в экономике её модернизация невозможна - хоть на общероссийском, хоть на региональном уровне.

8. Модернизация - это инноваторский подход к экономической организации производства. Уверены ли мы в поддержке такого подхода?

Что можно предложить практически?

1. Реальность такова, что в экономике Северного Кавказа наибольшую часть занимает неформальный сектор, то есть нелегализованная экономическая деятельность. Было бы правильным на неопределенный период отказаться от требования обязательной легализации неформального сектора, тем самым освободив их от бремени мало что значащих налоговых обязательств [7, 13].

2. То же надо сделать и по отношению к сектору рыночных услуг, в котором доминирует торговля, поскольку значительная ее часть всё равно прячется в тени и не отражается в статистике [18]. Это была бы не абстрактная, а конкретная либерализация экономики в границах данного региона.

3. В северокавказском социуме по разным причинам гипертрофированы такие общероссийские негативные явления, как суперэтатизм, бюрократизм, централизм, коррупция, монополизм. И эта гипертрофия конкретизирует содержание модернизации северокавказской экономики: необходим переход к альтернативной экономической модели, которой присущи минимальное присутствие государства в экономике, приоритетность позиций гражданского общества, расширение сферы свободного предпринимательства, реальная борьба с монополизмом.

4. Отдельные черты современной экономической политики Центра напоминают мне далёкую и забытую сегодня «политику военного коммунизма». А раз так, то для 
Мамедов О.Ю. Стратегия динамики региональной экономики: от модернизации экономики к модернизации производства!

формирования и модернизации экономики на Северном Кавказе необходимо внедрить региональный вариант северокавказского нэпа - предоставление всем участникам регионального рынка реальной рыночной свободы.

5. Рыночные реформы должны принести немедленный, ощутимый эффект:

1) российская (а с ней и северо-кавказская) экономика объективно движется к «либеральной экономической модели», в которой не экономика будет обслуживать государство, а государство - экономику! И только тогда, освобожденная от забот о государстве, экономика сможет повернуться, наконец, к заботам общества. Но для Северного Кавказа ускоренный переход к либеральной экономике особенно важен - неизбежное в период экономического кризиса сокращение федеральной бюджетной поддержки возможностей государства может вообще обернуться здесь катастрофой;

2) в то время как весь мир демонстрирует необратимость процесса урбанизации, в республиках Северного Кавказа сельское население в последние годы стало превышать городское. Неужели здесь история пошла вспять? Нет, таковы последствия известных политических катаклизмов, да и экономический кризис легче пережить на селе. Но жизнь на селе малодоходна, преобладает натуральное хозяйство, которое всегда ориентировано на выживание. Вот почему модернизация дагестанской экономики должна включать «дорожную карту» прямой реальной поддержки большинства категорий сельского и городского населения;

3) в регионе сложилась антиэффективная финансовая система использования государственных ресурсов. Вот ее результаты: отставание по ключевым экономическим показателям от других регионов (валовой региональный продукт на душу населения и производительность труда); развитие не реального сектора экономики, а сектора государственного управления и сферы социальных услуг (на Северном Кавказе - 55 \%, в РФ - 16 \%), поэтому и уровень безработицы здесь в 2-3 раза выше среднероссийского; дотационность консолидированного бюджета (доходя по отдельным республикам до $80-90 \%)$.

Вот почему модернизация северо-кавказской экономики невозможна без построения здесь современной эффективной финансовой системы [11]! Это значит, что финансовой опорой здесь могут быть только внутренние ресурсы. Вот и давайте выращивать и защищать главный их источник здесь - малый бизнес [20].

Экономисты - мужественные люди: несмотря на трудности, они упорно обсуждают концептуальные аспекты экономической модернизации.

И это правильно - с каждым упущенным днём осуществление модернизации становится всё актуальнее. В результате у нас появился своеобразный критерий реализации модернизации - пока о ней будут размышлять на конференциях теоретики, а не практики, это будет означать, что модернизация пребывает всё ещё на стадии обдумывания.

Нашим экономическим реформам свойствены энергичность на начальном этапе и её отсутствие - на этапе реализации. Отсюда и разочаровывающее несовпадение грандиозных масштабов замысла реформы и скромных масштабов её результатов. Удастся ли на этот раз преодолеть эту странную традицию?

Модернизация экономики актуализирует обычно игнорируемый аспект - а действительно ли российские регионы, включая регионы Северного Кавказа, убыточны и потому требуют дотационного финансирования?

На этот вопрос мы должны дать прямой ответ профессиональных экономистов российские регионы убыточны по меркам сегодняшнего бюджетного устройства. Отсюда следует принципиально важный вывод - стоит перестроить экономику на её 
Мамедов О.Ю. Стратегия динамики региональной экономики: от модернизации экономики к модернизации производства!

«естественных» (рыночно-предпринимательских) началах, и эта убыточность исчезнет. Всем надо понять, и особенно начальству, что выстроенная сегодня система межбюджетных отношений (формирования и распределения бюджета) - самая отсталая, самая затхлая, самая советская (т. е. антиэкономическая) сфера, всё ещё сохраняющая все признаки антиэкономического устройства. Обычно приведённому тезису противопоставляют утверждение, что либералы возлагают надежду на «автоматические» результаты рыночных преобразований. И они бы появились, если бы весь постсоветский период мелкий, средний и крупный бизнес не пребывал в постоянной и всеохватной бюрократической узде. Я вспоминаю, в какой ужас приводили маленькие кооперативчики наши государственные предприятия: как только появились ростки рынка, так эффективные - по бюрократическим критериям - предприятия оказались неэффективными. Так и с регионами - дайте им свободу, дайте им право распоряжаться собственными доходами, наполните политический и правовой федерализм реальным экономическим содержанием, и вы увидите, что вся проблема убыточности российских регионов надумана, искусственно создана антиэкономическим устройством межбюджетного процесса.

И сделаю ещё одно предсказание - до тех пор, пока будет оставаться «вертикальная» модель бюджетного устройства экономики, будут преобладать убыточные, задолжавшие всем, регионы, и только несколько регионов станут рентабельными. На языке классической экономической науки отбирание у регионов того, что они сделали (региональный валовой внутренний продукт), называется «феодализмом», а «обратное» вбрасывание крох в регионы - «барством». Какой-то удивительный, небывалый в истории «барский феодализм» $[1,2]$. Продолжая сохранять антиэкономическое бюджетное устройство, мы непременно дойдём не только до экономического банкротства регионов [6], но и до банкротства макроэкономического уровня - антиэкономической системы бюджетного устройства «феодального барства».

И, пожалуй, самое главное - в устойчивости нынешней крайне неэффективной и несправедливой системы экономики, продолжающей, как и в советскую эпоху, обслуживать исключительно государство, а не народ. Экономическим механизмом, главной опорой и стабилизатором этой бесперспективной системы является вовсе не нефть или цены на неё, а бюджетный процесс, устроенный таким образом, чтобы выбирать максимум возможного из регионов и перенаправлять их на нужды региональной и центральной бюрократии. Так что, если в сложившейся сегодня экономической системе и есть точка опоры, ухватившись за которую можно, по уверению Архимеда, перевернуть Вселенную, так это замена в статусе главного потребителя необходимого и прибавочного продукта - общество, а не государство; это в нашей экономике называется «межбюджетные отношения».

В конкретно-экономической существующей бюджетной системе регионы обречены на убыточность и банкротство. Но только в этой системе. И может показаться, что спровоцированное антиэкономическим устройством банкротство регионов - дело каждого региона, но когда их число превышает критическую величину, то банкротом становится вся страна.

\section{Литература}

1. Актуальные проблемы модернизации региональной экономики: сб. научных трудов преподавателей экономического факультета. - Курган: Курганский государственный университет, 2013. 
Мамедов О.Ю. Стратегия динамики региональной экономики: от модернизации экономики к модернизации производства!

2. Актуальные проблемы развития региональной экономики: сб. материалов II Всероссийской научно-практической конференции // НИИ управления, экономики, политики и социологии ДГУНХ. ( 16 апреля 2016). - Махачкала, 20016.

3. Аскеров Н.С. Модернизация институтов традиционной культуры как фактор развития кризисной территории // Вестник Московского государственного университета культуры и искусств [научный журнал]. - 2014. - № 2 (58).

4. Аскеров Н.С. Национальные особенности в истории экономической мысли и современности // Вестник Дагестанского государственного университета. - 2004. Вып. 2. - С. 86-89.

5. Аскеров Н.С. Политическая экономия - методология исследования экономики России и её регионов. Вестник Дагестанского государственного университета. - 2015. Вып. 5. - С. 148-154.

6. Байрамова Ж.М. Региональные аспекты модернизации национальной экономики // Известия Пензенского государственного педагогического университета им. В.Г. Белинского. - 2011. - № 24. - С. 181-187.

7. Болдырева Л.В. Модернизация региональной финансовой системы в посткризисной экономике: автореф. дис. ... канд. эк. н. / Кубанский государственный университет. - Краснодар, 2011.

8. Бузгалин А.В., Колганов А.И. Политическая экономия и экономическая политика. Рынок. Капитал. Общество // TERRA ECONOMICUS. - 2016. - T. 14, № 1. C. 27-47.

9. Валентей С.Д., Бахтизин А.Р., Кольчугина А.В. Региональные ограничители модернизации российской экономики // Федерализм. - 2012. - № 4. - С. 165-178.

10. Ворошилова И.В., Родин Д.Я. Влияние кризисных явлений на модернизацию финансирования реального сектора региональной экономики // Финансы и кредит. 2009. - № 5 (341). - С. 64-70.

11. Герасимов В.Г., Ушаков В.А. Зарубежный опыт управления межбюджетными отношениями и целесообразность его применения в Российской Федерации // Вестник Воронежского государственного технического университета. -2011 . - Т. 7, № 4. C. $25-30$.

12. Горелова Г.В., Жертовская Е.В., Якименко М.В. Инновационная модернизация национальной и региональной экономик: предпосылки, принципы и приоритеты: монография. - Таганрог, 2014.

13. Денисенко Ю.Н. Модернизация системы регионального налогообложения в современной экономике России: дис. ... канд. эк. н. / Южный федеральный университет. - Ростов н/Д, 2011.

14. Кильчуков 3.Х., Галачиева С.В. Факторы модернизации российских региональных экономик в посткризисный период // Известия Кабардино-Балкарского научного центра РАН. - 2011. - № 1-2. - С. 57-62.

15. Корчагин П.В. Теория и практика модернизации региональной экономики // Вестник СамГУПС. - 2010. - № 4. - С. 128-132.

16. Мамедов О.Ю. В поисках «внеэкономического производства»// TERRA ECONOMICUS. - 2016. - T. 14, № 1. - C. 6-17.

17. Нуреев Р.М., Ахмадеев Д.Р. Формальная и неформальная занятость как «близнецы-братья»: современная российская практика // TERRA ECONOMICUS. 2015. - T. 13, № 3. - C. 16-33. 
18. Самханова Л.В. Формирование региональной политики развития малого предпринимательства в условиях модернизации экономики: автореф. дис. ... канд. эк. н. / Кисловодский институт экономики и права. - Кисловодск, 2011.

19. Тарасов E.O. Структурно-инновационные преобразования в экономике как фундаментальная основа ее модернизации: региональные аспекты // Региональная экономика: теория и практика. - 2010. - № 45. - С. 26-33.

20. Татуев A.А., Ашхотова Э.А. Диверсификация производства в процессе модернизации региональной экономики (на примере регионов Северо-Кавказского федерального округа) // Региональная экономика: теория и практика. - 2010. - № 29. - С. 2-9.

21. Резолюция «Дагестанского гражданского форума» // http://sevkavinform.ru).

Поступила в редакцию 5 июля 2017 г.

UDC 338.23

DOI: $10.21779 / 2500-1930-2017-32-3-76-81$

Strategy of dynamics of the regional economy: from economic modernization to the modernization of production

\section{O.Y. Mamedov}

Southern Federal University; Russia, 344006, Rostov-on-Don, Gorky street, 88; oktajmamedov@yandex.ru

The article reveals the issues of modernization of regional economic systems and describes the obstacles to be overcome on the way of modernization of regional economy. The authors justify the necessity of overcoming the dictates of the state in the economy, which is essential for the modernization both on the national and regional levels. The share of the state property is more than half the wealth of society, in case of indirect control it is over three quarters - in this respect the government is the most inefficient owner.

The author proposes to temporarily refuse the obligatory legalization of the informal sector, thereby freeing them from the burden of tax liabilities.

The author demonstrates some negative aspects of the Russian reality which are exaggerated in the North Caucasian region: superetatism, bureaucracy, centrism, corruption, monopoly. On this basis the conclusion is made about the content of the modernization of the North Caucasian economy: the transition to an alternative economic model, which has a minimal state presence in the economy, the priority of civil society perspectives, the expansion of free enterprise, a real struggle against monopoly.

Keywords: bureaucracy, centralism, monopolism, modernization, an effective financial system, liberalization.

Received 5 July, 2017 